\title{
Compensation for the effects of ambient conditions on the calibration of multi-capillary pressure drop standards*
}

\author{
by

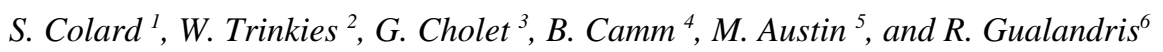 \\ ${ }^{1}$ ALTADIS Research Centre, 4 rue André Dessaux, 45404 Fleury-Les-Aubrais, France \\ ${ }^{2}$ British American Tobacco Germany GmbH, Bayreuth, Germany \\ ${ }^{3}$ Sodim Instrumentation, Fleury-Les Aubrais, France \\ ${ }^{4}$ Borgwaldt-kc, Hamburg, Germany \\ ${ }^{5}$ Cerulean, Milton-Keynes, UK \\ ${ }^{6}$ Philip Morris International, Neuchâtel, Switzerland
}

\section{SUMMARY}

Cigarette draw resistance and filter pressure drop (PD) are both major physical parameters for the tobacco industry. Therefore these parameters must be measured reliably. For these measurements, specific equipment calibrated with PD transfer standards is used. Each transfer standard must have a known and stable PD value, such standards usually being composed of several capillary tubes associated in parallel. However, PD values are modified by ambient conditions during calibration of such standards, i.e. by temperature and relative humidity (RH) of air, and atmospheric pressure. In order to reduce the influence of these ambient factors, a simplified model was developed for compensating the effects of ambient conditions on the calibration of multi-capillary PD standards.

Experiments demonstrated that the standards exhibited a non-linear airflow component, which explains why atmospheric pressure has an effect on the calibrated value. The standards were also found to show a high degree of sensitivity to ambient temperature, but low sensitivity to RH. The developed compensation has been applied successfully to calibration results with wide ranging ambient conditions. Finally, to simplify the process of compensation, a simple equivalent mathematical model was developed. In conclusion, the results of this study demonstrate the benefits of the proposed compensation in minimising the effects of ambient conditions. [Beitr. Tabakforsch. Int. 21 (2004) 167-174]

\section{ZUSAMMENFASSUNG}

Der Zugwiderstand von Zigaretten und der Druckabfall in Filterstäben sind beides wichtige physikalische Parameter für die Cigarettenindustrie. Aus diesem Grund müssen diese Parameter zuverlässig erfasst werden können. Für diese Messungen werden spezielle Meßsysteme, die mit Zugwiderstands-Kalibrierstandards geeicht werden, eingesetzt. Jeder dieser Kalibrierstandards, im allgemeinen aus mehreren parallel angeordneten Kapillarröhrchen aufgebaut, muss einen bekannten und stabilen Druckabfall aufweisen. Allerdings werden die Druckabfallwerte während des Kalibriervorganges durch Umgebungsbedingungen, wie zum Beispiel Temperatur, Luftfeuchtigkeit und Luftdruck beeinflusst. Zur Reduzierung dieser Umgebungseinflüsse wurde ein vereinfachtes Modell entwickelt, welches eine Kompensation dieser Umgebungseinflüsse auf die Kalibrierung von multikapillaren Zugwiderstandstandards ermöglicht.

Experimente zeigten, dass die Standards einen nicht linearen Strömungsanteil aufweisen, welcher den Einfluss des Luftdruckes auf den Kalibrierwert erklärt. Die Standards zeigten außerdem eine hohe Empfindlichkeit gegenüber der Umgebungstemperatur jedoch eine geringe Empfindlichkeit gegenüber der relativen Luftfeuchte. Die entwickelte Kompensation wurde erfolgreich bei Kalibrierwerten angewandt, die über einen weiten Schwankungsbereich der Umgebungsbedingungen ermittelt wurden. Schließlich wurde, um die Kompensation zu vereinfachen, ein einfaches gleichwertiges mathematisches Model entwickelt. Zusammengefasst zeigen 


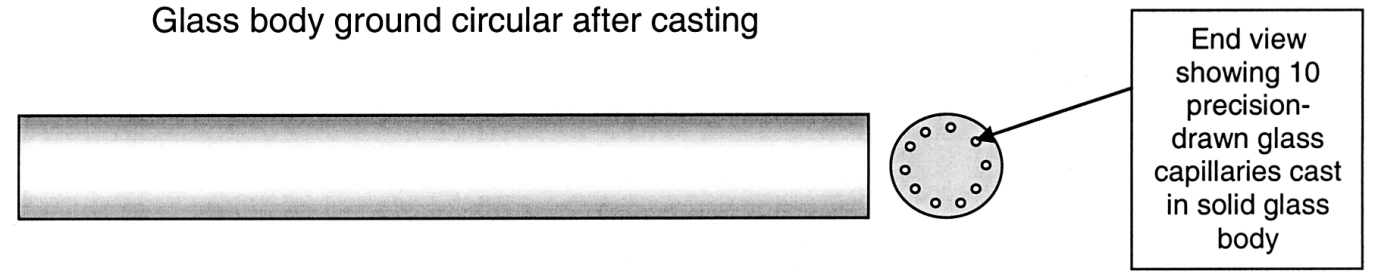

Figure 1. Essential properties of glass multicapillary PD calibration standard

die Ergebnisse dieser Studie die Vorteile der vorgeschlagenen Kompensation, die eine Minimierung von Einflüssen der Umgebungsbedingungen ermöglicht. [Beitr. Tabakforsch. Int. 21 (2004) 167-174]

\section{RESUME}

La résistance au tirage des cigarettes et la perte de charge à travers les filtres sont deux paramètres importants pour l'industrie du tabac. Ces paramètres doivent donc être mesurés avec fiabilité. Pour effectuer ces mesures, des équipements spécifiques calibrés avec des piges étalons de transfert sont utilisés. A chaque étalon de transfert doit correspondre une valeur de perte de charge connue et stable dans le temps. De tels étalons sont habituellement constitués de plusieurs tubes capillaires disposés en parallèle. Cependant, les valeurs de perte de charge à travers de tels étalons sont affectées par les conditions ambiantes, c'est à dire par la température et l'humidité relative de l'air, et par la pression atmosphérique. Dans le but de réduire l'influence de ces facteurs, un modèle physique simple a été développé pour compenser leurs effets sur les résultats d'étalonnage.

Des expériences ont montré que l'écoulement de l'air à travers les étalons présentait une composante de flux non linéaire, ce qui explique pourquoi la pression atmosphérique affecte les résultats d'étalonnage. Il a été montré également que les valeurs des pertes de charge à travers les étalons étaient significativement affectées par la température ambiante, mais moins par l'humidité relative de l'air. Le modèle de compensation développé a été appliqué avec succès à des résultats d'étalonnage obtenus avec des conditions ambiantes particulièrement différentes. Finalement, afin de simplifier le processus de compensation, un modèle mathématique a été proposé. En conclusion, les résultats de cette étude ont démontré l'intérêt de la réduction des effets des conditions ambiantes sur les résultats d'étalonnage de piges multi-capillaires. [Beitr. Tabakforsch. Int. 21 (2004) 167-174]

\section{INTRODUCTION}

Cigarette draw resistance and filter pressure drop (PD) are both major physical parameters for the tobacco industry, and it is important that they are measured reliably. For these measurements, equipment calibrated with PD transfer standards is used. PD standards are normally composed of ten capillary tubes associated in parallel, the structure being made of glass (Figure 1). Each standard must have a known and stable value ascribed to it.
In practice, PD standards are calibrated by drawing a known, constant volumetric flow through the PD standard $(17.5 \mathrm{~mL} / \mathrm{s}$, measured at the exit to the standard) drawn from an environment at standard atmospheric conditions (as defined in the International Standard (ISO 3402). The resulting pressure difference across the standard is then measured and expressed as the PD of the standard.

During the calibration, the PD standard is held by a holder within a draught screen which is designed to provide reproducible conditions for the flow and pressure connections and to have negligible effect on the measured value. Air is flowed through the standard until a constant PD reading is achieved (indicating thermal equilibrium between the standard and the measurement air). The actual airflow is then measured concurrent with the stabilised PD measurement, together with the actual temperature, humidity and atmospheric pressure within the draught screen. A diagram showing the essential features of this system is shown in Figure 2. It is also necessary to note that this process applies only to the calibration of PD calibration standards and not to the calibration of PD measuring instruments. This calibration uses a different technique that is dealt with in ISO 6565 and is outside the scope of this article.

Pressure drop values are influenced by the ambient conditions during calibration, i.e. by temperature $T$ and relative humidity $\mathrm{RH}$ of air, and atmospheric pressure $P$. One way of reducing the influence of these ambient factors is to apply mathematical compensation. A suitable compensation formula can be derived by considering the effects of ambient conditions on the basic characteristics of the measurement air. When calibrating PD standards, the objective of the compensation formula is the calculation of a pressure drop value, $\mathrm{PD}_{\mathrm{S}}$, at standard ambient conditions as defined in ISO 6565, CORESTA (Cooperation Centre for Scientific Research Relative to Tobacco) RM41 and ISO $3402\left(T_{\mathrm{S}}=22{ }^{\circ} \mathrm{C}, \mathrm{RH}_{\mathrm{S}}=60 \%, P_{\mathrm{S}}=1013 \mathrm{hPa}\right.$, outlet airflow $\left.Q_{\mathrm{S}}=17.5 \mathrm{~mL} / \mathrm{s}\right)$, from PD measurements undertaken at different conditions ( $T, \mathrm{RH}, P, Q)$.

This work has been done by the CORESTA Task Force "Calibration of Pressure Drop Transfer Standards" and only applies to the most commonly used standards comprised of 10 glass capillary tubes. Figure 3 shows an enlarged front view of such standards.

\section{DERIVATION OF A SIMPLIFIED MODEL}

Assuming that the air is incompressible, the behaviour of the flow across one capillary of a transfer standard can be described as shown in Figure $4(1)$, with $\Delta p_{\mathrm{B}}=$ differential pressure in the tube; $\Delta p_{\text {in }}=$ differential pressure at inlet 


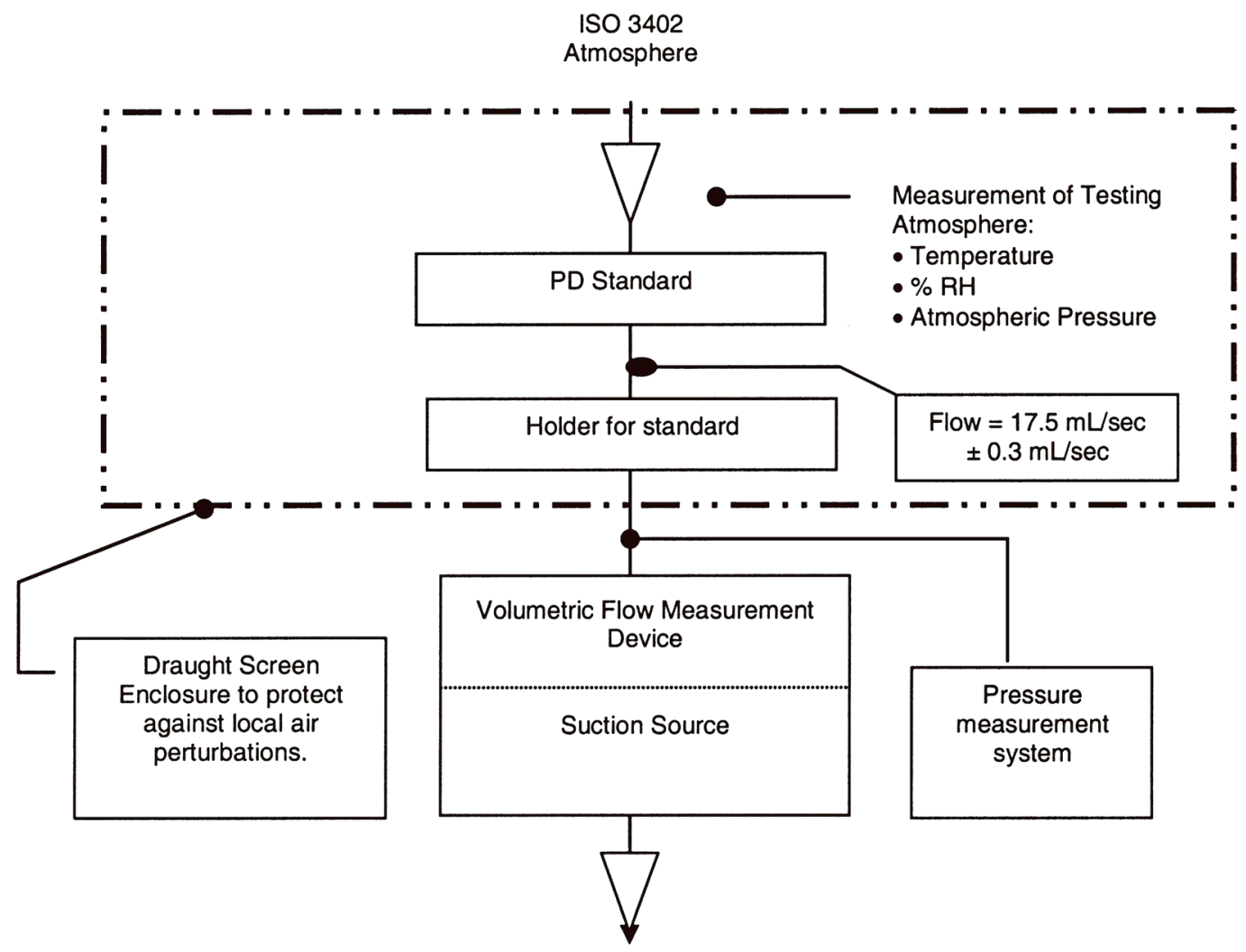

Figure 2. Essential features of arrangement for calibration of multicapillary PD standards

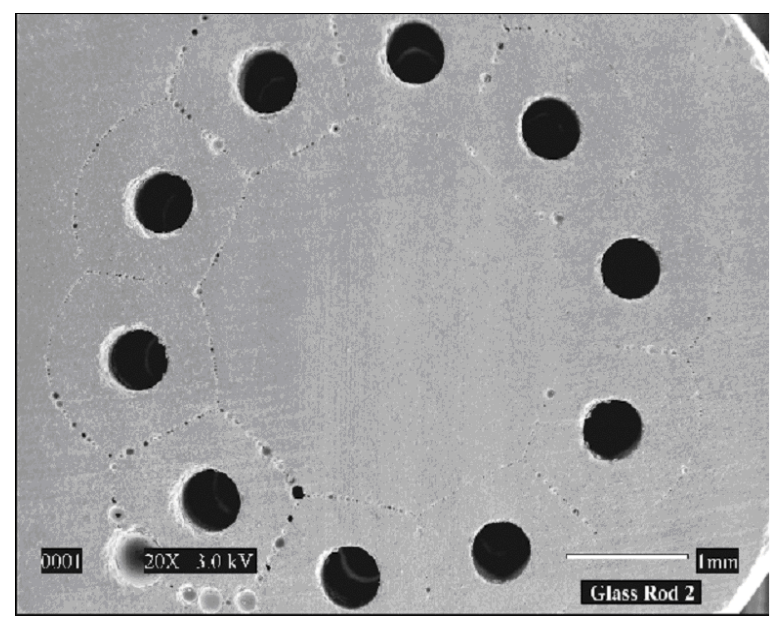

Figure 3. Front view of a PD standard comprised of 10 glass capillary tubes (Photograph provided by J. Don Gombash of Celanese Acetate Tow, US.) end; $\Delta p_{\text {vout }}=$ differential pressure at outlet end; $r_{\mathrm{i}}=$ radius of tube; $f_{2}=$ area of tube; $f_{3}=$ area at output end; $l=$ length of tube; $\eta=$ dynamic viscosity; $\rho=$ density; $w=$ velocity; $Q=$ volumetric flow; $\xi_{\mathrm{E}}=$ drag coefficient.

Assumption of incompressibility can be made, considering that differences of pressure $\Delta p$ are much lower than the atmospheric pressure.

The ambient conditions modify two physical parameters that influence the airflow behaviour namely the viscosity $\eta$ and the density $\rho$ of air.

RASMUSSEN (2) has developed a calculation procedure for these two parameters from which, by fitting $\left(R^{2}=99.9 \%\right)$ we deduced two simplified formulae covering wide ranges of ambient conditions generated in the laboratories [18-26 $\left.{ }^{\circ} \mathrm{C}\right],[50-70 \%],[900-1100 \mathrm{hPa}]$ :

$$
\begin{aligned}
\eta(T, \mathrm{RH})(\mathrm{Pa} \cdot \mathrm{s})= & 4.703 \times 10^{-6}+4.587 \times 10^{-8} \\
& \times T(\mathrm{~K})-4.944 \times 10^{-10} \times \mathrm{RH}(\%)
\end{aligned}
$$

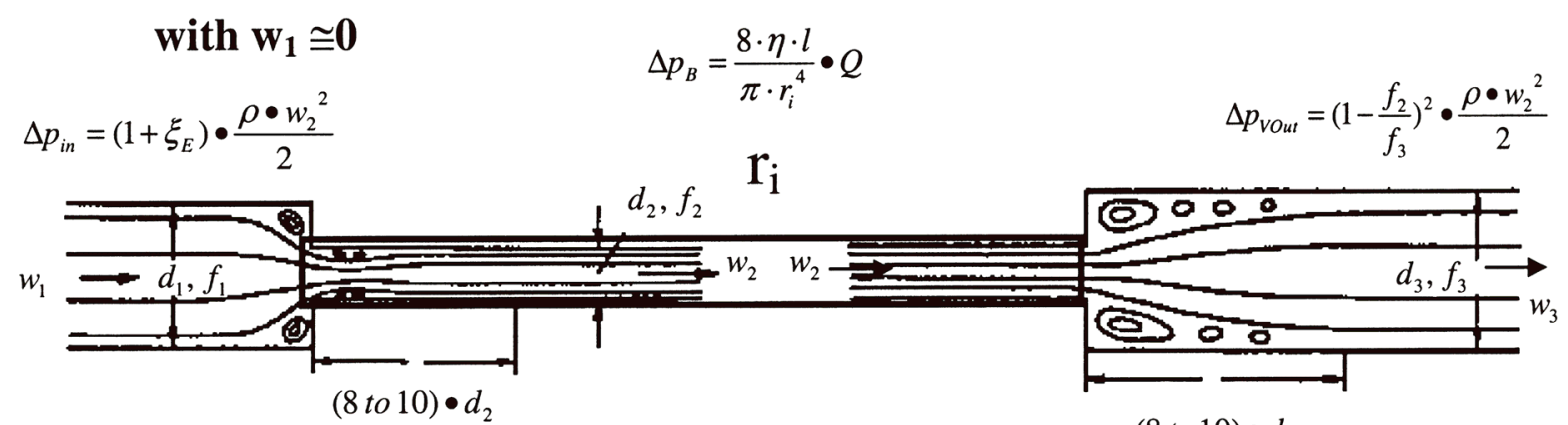

Figure 4. Airflow across a capillary standard 


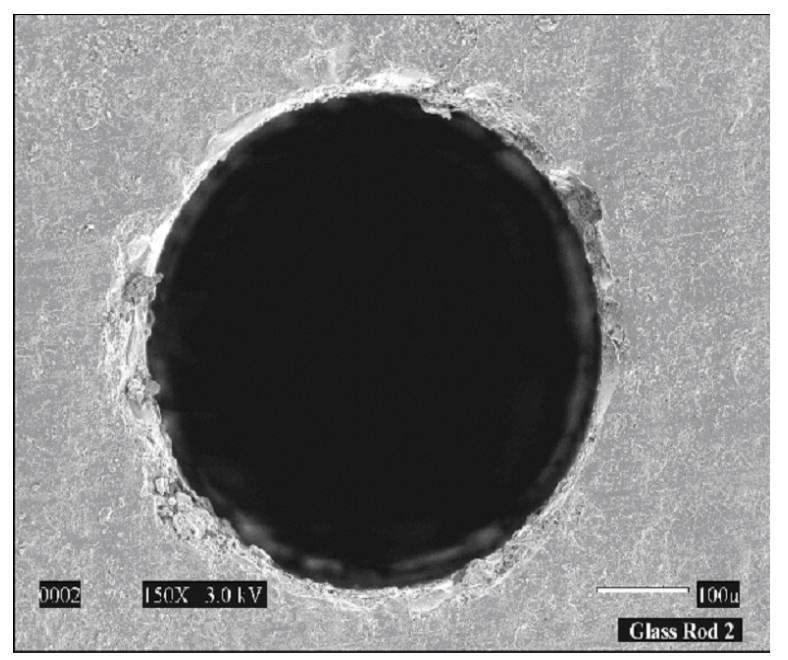

Figure 5. Imperfections of the hole edges (Photograph provided by J. Don Gombash of Celanese Acetate Tow, US.)

$$
\begin{aligned}
\rho(P, T)\left(\mathrm{kg} / \mathrm{m}^{3}\right)= & 2.032 \times 10^{-1}-7.137 \times 10^{-4} \times T(\mathrm{~K}) \\
& +2.281 \times 10^{-5} \times P(\mathrm{~Pa})-3.728 \times 10^{-8} \\
& \times T(\mathrm{~K}) \times P(\mathrm{~Pa})
\end{aligned}
$$

The Rasmussen data shows the air density changes by only $0.2 \%$ for a change in $\mathrm{RH}$ from $50 \%$ to $70 \%$. Hence, the effect of RH can be neglected in the estimation of $\rho$.

The dominant physical factors in the various zones of the capillary standard are different. Flow in the capillary tubes is limited by viscosity (Reynolds number <500) whereas flow at the entry and exit exhibits a kinetic component (density dependent). As a consequence, when constructing a compensation formula, it is necessary to develop different models for each of the flow types. Three conditions have been considered.

\section{Linear behaviour of pressure drop vs. the airflow}

Historically, it was presumed that the airflow through the capillary tube was linear (laminar, see Hagen-Poiseuille equation in Figure 4). The calculated Reynolds number of the existing ranges of calibration standards never exceeds 500. In this case, the PD is proportional to the air viscosity and to the volumetric airflow. In accordance with the perfect gas law it can be written:

$$
\begin{aligned}
\frac{\mathrm{PD}_{\mathrm{S}}}{\mathrm{PD}} & =\frac{\eta\left(T_{\mathrm{S}}, \mathrm{RH}_{\mathrm{S}}\right) \times Q_{\mathrm{S}}\left(P_{\mathrm{S}}, T_{\mathrm{S}}, \mathrm{PD}_{\mathrm{S}}\right)}{\eta(T, \mathrm{RH}) \times Q(P, T, \mathrm{PD})} \\
& =\frac{\eta\left(T_{\mathrm{S}}, \mathrm{RH}_{\mathrm{S}}\right) \times T_{\mathrm{S}} \times(P-\mathrm{PD})}{\eta(T, \mathrm{RH}) \times T \times\left(P_{\mathrm{S}}-\mathrm{PD}_{\mathrm{S}}\right)}
\end{aligned}
$$

The development of the previous formula gives a second order polynomial expression that is easy to solve:

$$
\mathrm{PD}_{\mathrm{S}}^{2}-P_{\mathrm{S}} \times \mathrm{PD}_{\mathrm{S}}+\frac{\eta_{\mathrm{S}} \times T_{\mathrm{S}}}{\eta \times T} \times(P-\mathrm{PD}) \times \mathrm{PD}=0
$$

The previous equations assume that the mass flow is constant; the standard PD value with an outlet volumetric airflow equal to $17.5 \mathrm{~mL} / \mathrm{s}$ is then:

$$
\mathrm{PD}_{\mathrm{S}, 17.5 \mathrm{~mL} / \mathrm{s}}=\mathrm{PD}_{\mathrm{s}} \times \frac{17.5}{Q\left(P_{\mathrm{S}}, T_{\mathrm{S}}, \mathrm{PD}_{\mathrm{S}}\right)}
$$

Non-linear behaviour of pressure drop vs. the airflow

If a totally non-linear (turbulent) airflow is considered, the PD value is proportional to the air density and to the square of the volumetric airflow. In accordance with the perfect gas law it can be written:

$$
\begin{aligned}
\frac{\mathrm{PD}_{\mathrm{S}}}{\mathrm{PD}} & =\frac{\rho\left(P_{\mathrm{S}}, T_{\mathrm{S}}\right) \times Q_{\mathrm{S}}^{2}\left(P_{\mathrm{S}}, T_{\mathrm{S}}, \mathrm{PD}_{\mathrm{S}}\right)}{\rho(P, T) \times Q^{2}(P, T, \mathrm{PD})} \\
& =\frac{\rho\left(P_{\mathrm{S}}, T_{\mathrm{S}}\right)}{\rho(P, T)} \times\left(\frac{T_{\mathrm{S}} \times(P-\mathrm{PD})}{T \times\left(P_{\mathrm{S}}-\mathrm{PD}_{\mathrm{S}}\right)}\right)^{2}
\end{aligned}
$$

The development of the previous formula gives a third order polynomial expression:

$$
\begin{aligned}
\mathrm{PD}_{\mathrm{S}}^{3} & -2 \times P_{\mathrm{S}} \times \mathrm{PD}_{\mathrm{S}}^{2}+P_{\mathrm{S}}^{2} \times \mathrm{PD}_{\mathrm{S}}-\frac{\rho_{\mathrm{S}} \times T_{\mathrm{S}}^{2}}{\rho \times T^{2}} \\
& \times \mathrm{PD} \times(P-\mathrm{PD})^{2}=0
\end{aligned}
$$

The standard PD value with an outlet volumetric airflow equal to $17.5 \mathrm{~mL} / \mathrm{s}$ is then:

$$
\mathrm{PD}_{\mathrm{S}, 17.5 \mathrm{~mL} / \mathrm{s}}=\mathrm{PD}_{\mathrm{S}} \times\left(\frac{17.5}{Q\left(P_{\mathrm{S}}, T_{\mathrm{S}}, \mathrm{PD}_{\mathrm{S}}\right)}\right)^{2}
$$

Linear + non-linear behaviour of pressure drop vs. the airflow

If it can be assumed that the airflow through the capillary tubes is linear, non-linear airflow could occur at the inlet and the outlet of the standard due to sudden reduction and enlargement respectively (see Figure 4). The imperfections of the capillary edges (Figure 5) can also induce turbulence. Although two non-linear parts could be considered (inlet + outlet) in addition to a linear one, it is possible to simplify this by considering an airflow composition of one linear part and one non-linear part. Assuming that the air is incompressible in the capillary tubes, and also, that the air speed $w_{2}$ (see Figure 4) is constant, PD at inlet and outlet can be grouped.

$$
\Delta p_{\text {in \& out }} \cong\left(\left(1+\xi_{\mathrm{E}}+\left(1-\frac{f_{2}}{f_{3}}\right)^{2}\right) \times \frac{\rho \times w_{2}^{2}}{2}\right.
$$

This approach has the advantage of simplifying the modelling because it allows the introduction of a unique parameter $x$ related to a global degree of non linearity, such that:

$$
\begin{aligned}
& \mathrm{PD}_{1}=x \times \mathrm{PD} \\
& \mathrm{PD}_{2}=(1-x) \times \mathrm{PD}
\end{aligned}
$$

where $\mathrm{PD}_{1}$ and $\mathrm{PD}_{2}$ are the pressure differences observed across the non-linear part and across the linear part respectively. The measured pressure drop PD is the sum of $\mathrm{PD}_{1}$ and $\mathrm{PD}_{2}$ (Figure 6).

The validity of this approximation is evaluated in the next section "Results and discussion". 


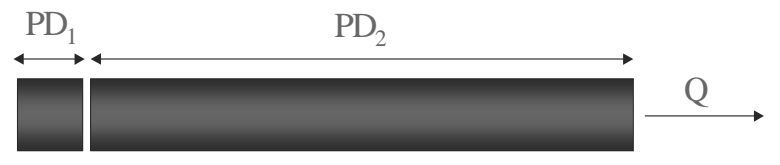

$\mathrm{PD}=\mathrm{PD}_{1}+\mathrm{PD}_{2}$

Figure 6. Composition of the PD components across a standard

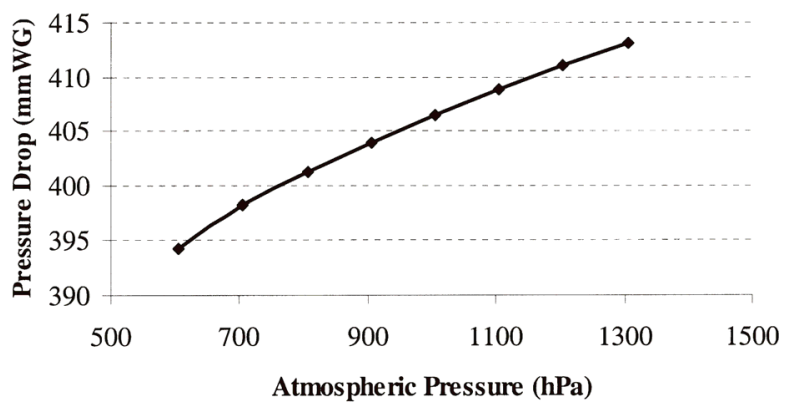

Figure 7. PD vs. atmospheric pressure (with $T=22.4{ }^{\circ} \mathrm{C}, \mathrm{RH}=$ $1 \%)$

In accordance with the model of a linear airflow, the linear component may be expressed by the following equation where $\mathrm{PD}_{1 \mathrm{~S}}$ and $\mathrm{PD}_{2 \mathrm{~S}}$ are the unknown parameters:

$$
\begin{aligned}
\mathrm{PD}_{2 \mathrm{~S}}^{2} & -\left(P_{\mathrm{S}}-\mathrm{PD}_{1 \mathrm{~S}}\right) \\
& \times \mathrm{PD}_{2 \mathrm{~S}}+\frac{\eta_{\mathrm{S}} \times T_{\mathrm{S}}}{\eta \times T} \times(P-\mathrm{PD}) \times \mathrm{PD}_{2}=0
\end{aligned}
$$

In accordance with the model of a non-linear airflow, the non-linear component can be expressed by :

$$
\begin{aligned}
\mathrm{PD}_{1 \mathrm{~S}}^{3} & -2 \times P_{\mathrm{S}} \times \mathrm{PD}_{1 \mathrm{~S}}^{2}+P_{\mathrm{S}}^{2} \times \mathrm{PD}_{1 \mathrm{~S}} \\
& -\frac{\rho_{\mathrm{S}} \times T_{\mathrm{S}}^{2}}{\rho \times T^{2}} \times \mathrm{PD}_{1} \times\left(P-\mathrm{PD}_{1}\right)^{2}=0
\end{aligned}
$$

where $\mathrm{PD}_{1 \mathrm{~S}}$ is the unknown parameter.

Therefore, in the case of a linear and non-linear airflow, two equations were obtained having two unknown parameters, $\mathrm{PD}_{1 \mathrm{~S}}$ and $\mathrm{PD}_{2 \mathrm{~S}}$. After resolving these equations, in this case using an iterative Newtonian method (3), the standard
PD value with an outlet volumetric airflow of $17.5 \mathrm{~mL} / \mathrm{s}$ is then approximated by:

$$
\begin{aligned}
\mathrm{PD}_{\mathrm{S}, 17.5 \mathrm{~mL} / \mathrm{s}} \cong & \mathrm{PD}_{1 \mathrm{~S}} \times\left(\frac{17.5}{Q\left(P_{\mathrm{S}}, T_{\mathrm{S}}, \mathrm{PD}_{\mathrm{S}}\right)}\right)^{2} \\
& +\mathrm{PD}_{2 \mathrm{~S}} \times\left(\frac{17.5}{Q\left(P_{\mathrm{S}}, T_{\mathrm{S}}, \mathrm{PD}_{\mathrm{S}}\right)}\right)
\end{aligned}
$$

Note: The compensation models are available from the authors as a spreadsheet for facilitating its use.

\section{RESULTS AND DISCUSSION}

Experiments were carried out to estimate the degree of the non-linearity of the PD standard required by the model (Eqn. [5]). This estimate was then tested by applying the compensation formula to the calibration measurements of multi-capillary glass standards made under a range of different ambient conditions. These measurements were carried out using two different calibration systems meeting the requirements shown in Figure 2.

\section{Compensation for atmospheric pressure effects - Degree of non linearity $\mathrm{x}$}

Experiments show a very small non-linear behaviour for the relationship of PD values vs. airflow for multi-capillary standards. This excludes the hypothesis of a purely quadratic dependence of PD on airflow (see section on nonlinear airflow). However, experiments also show that the PD measurement is affected by the atmospheric pressure (Figure 7). This observation is in agreement with the results obtained by KEITH (4) and means that the air density has an influence on the measured PD. The hypothesis of a totally linear dependence of PD on airflow can also be excluded (see section on linear airflow). Therefore, it can be concluded that the airflow through a multi-capillary standard is partly linear, and partly non-linear.

The degree of non-linearity dependence of PD on airflow $x$, which allowed the best compensation, i.e. a minimal standard deviation, $s$, for $\mathrm{PD}_{\mathrm{s}}$, was determined from measurements of PD vs. atmospheric pressure over the range [900-1100 hPa]. The results obtained by using Eqns. [5] to [8], are given in Table 1.

It has been assumed here, that the degree of non-linearity $x$, was only dependent on the standard geometry (or PD

Table 1. PD levels and optimal degree of non linearity minimising the standard deviations $(s)$ of the compensated values

\begin{tabular}{c|c|c|c|c|c|c|c|c|c|c|c}
\hline \multicolumn{2}{c|}{$200 \mathrm{mmWG}(x=3.9 \%)$} & \multicolumn{3}{c|}{$400 \mathrm{mmWG}(x=5 \%)$} & \multicolumn{2}{c|}{$600 \mathrm{mmWG}(x=5.4 \%)$} & \multicolumn{3}{c}{$800 \mathrm{mmWG}(x=6.0 \%)$} \\
\hline $\begin{array}{c}\mathrm{P}_{\text {atm }} \\
(\mathrm{hPa})\end{array}$ & $\begin{array}{c}\mathrm{PD} \\
(\mathrm{mmWG})\end{array}$ & $\begin{array}{c}\mathrm{PD}_{\mathrm{s}, 17.5} \\
(\mathrm{mmWG})\end{array}$ & $\begin{array}{c}\mathrm{P}_{\text {atm }} \\
(\mathrm{hPa})\end{array}$ & $\begin{array}{c}\mathrm{PD} \\
(\mathrm{mmWG})\end{array}$ & $\begin{array}{c}\mathrm{PD}_{\mathrm{s}, 17.5} \\
(\mathrm{mmWG})\end{array}$ & $\begin{array}{c}\mathrm{P}_{\text {atm }} \\
(\mathrm{hPa})\end{array}$ & $\begin{array}{c}\mathrm{PD} \\
(\mathrm{mmWG})\end{array}$ & $\begin{array}{c}\mathrm{PD}_{\mathrm{s}, 17.5} \\
(\mathrm{mmWG})\end{array}$ & $\begin{array}{c}\mathrm{P}_{\text {atm }} \\
(\mathrm{hPa})\end{array}$ & $\begin{array}{c}\mathrm{PD} \\
(\mathrm{mmWG})\end{array}$ & $\begin{array}{c}\mathrm{PD}_{\mathrm{s}, 17.5} \\
(\mathrm{mmWG})\end{array}$ \\
\hline 902.7 & 195.9 & 196.4 & 905.3 & 404.0 & 405.7 & 906 & 591.4 & 594.7 & 907.3 & 785.3 & 791.4 \\
1002.7 & 196.9 & 196.5 & 1005.3 & 406.5 & 405.6 & 1006 & 595.8 & 594.6 & 1007.3 & 792.2 & 791.2 \\
1102.7 & 197.6 & 196.4 & 1105.3 & 408.9 & 405.7 & 1106 & 599.6 & 594.7 & 1107.3 & 798.5 & 791.3 \\
$s$ & 0.85 & 0.04 & $s$ & 2.45 & 0.08 & $s$ & 4.10 & 0.07 & $s$ & 6.60 & 0.12 \\
\hline
\end{tabular}




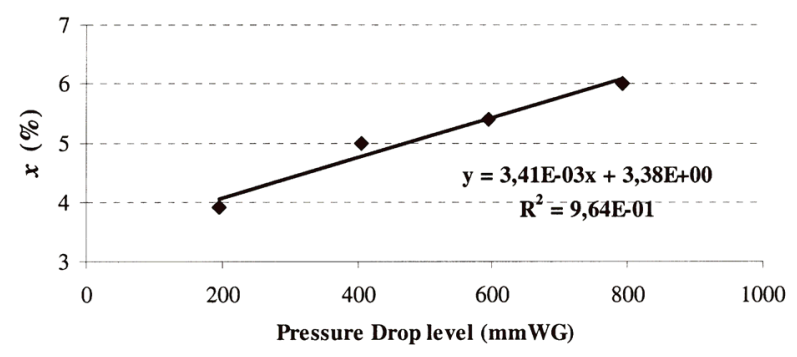

Figure 8. Degree of non linearity vs. PD level

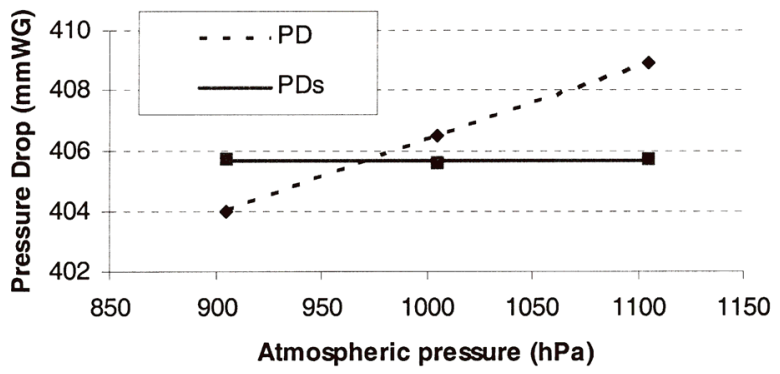

Figure 9. Compensation for atmospheric pressure effects (with $T=22.4^{\circ} \mathrm{C}$ )

level at $17.5 \mathrm{~mL} / \mathrm{s})$. However, $x$ is also influenced by the volumetric airflow level and ambient conditions. These influences can safely be neglected here since, during the calibration of the PD standard, the ISO standard requires these parameters to be held within a particularly narrow range.

The sensitivity of PD to the atmospheric pressure varies from $0.22 \%$ to $0.41 \%$ of the PD value per $50 \mathrm{hPa}$ for 200 to $800 \mathrm{mmWG}$ PD levels respectively.

The increasing of $x$ with increasing PD levels could be attributed to the decreasing diameters of the capillaries.
This may induce inertial effects. From the previous results, a linear curve has been fitted by regression in order to calculate the optimum value of $x$ whatever the PD value (Figure 8).

The compensation for the atmospheric pressure effects is illustrated on Figure 9.

Having established $x$, it is now possible to validate the compensation process using experimental data with widely varying ambient conditions, and the Eqns. [5] to [8].

\section{Compensation for ambient temperature effects}

In order to evaluate compensation for the effects of temperature, the variation of the PD vs. ambient temperature over the range [18-28 ${ }^{\circ} \mathrm{C}$ ] was measured. The degree of non-linearity was adjusted according to the PD level using the linear relation, drawn in Figure 8 and compensated values were calculated using Eqns. [5] to [8]. Compensation produced the results given in Table 2 .

Table 2 clearly shows that the compensation significantly decreased the standard deviation of the measured values over the temperature range $\left[18-28{ }^{\circ} \mathrm{C}\right]$. These results are illustrated graphically on Figure 10 by the reduction of the absolute value of the slope of the curve.

From the model, the theoretical sensitivity of PD values to ambient temperature at $22{ }^{\circ} \mathrm{C}$ is about $0.23 \%$ of the PD value per degree Celsius.

\section{Compensation for relative humidity effects}

In order to evaluate compensation for the effects of $\mathrm{RH}$, the variation of the PD vs. RH over the range [25-80\% $\mathrm{RH}]$ was measured.

In spite of a wide range of variation for the relative humidity, only a slight variation of the PD was detected after approximate temperature compensation $(0.23 \%$ of $\left.\mathrm{PD} /{ }^{\circ} \mathrm{C}\right)$. In Table 3 , a comparison of the theoretical relative

Table 2. Reduction of the standard deviation, $s$, following compensation

\begin{tabular}{|c|c|c|c|c|c|c|c|c|c|c|c|}
\hline \multicolumn{3}{|c|}{$200 \mathrm{mmWG}$} & \multicolumn{3}{|c|}{$400 \mathrm{mmWG}$} & \multicolumn{3}{|c|}{$600 \mathrm{mmWG}$} & \multicolumn{3}{|c|}{$800 \mathrm{mmWG}$} \\
\hline $\begin{array}{c}\mathrm{T} \\
\left({ }^{\circ} \mathrm{C}\right)\end{array}$ & $\begin{array}{c}\mathrm{PD} \\
(\mathrm{mmWG})\end{array}$ & $\begin{array}{c}\mathrm{PD}_{\mathrm{s}, 17.5} \\
\text { (mmWG) }\end{array}$ & $\begin{array}{c}\mathrm{T} \\
\left({ }^{\circ} \mathrm{C}\right)\end{array}$ & $\begin{array}{c}\text { PD } \\
(m m W G)\end{array}$ & $\begin{array}{c}\mathrm{PD}_{\mathrm{s}, 17.5} \\
\text { (mmWG) }\end{array}$ & $\begin{array}{c}\mathrm{T} \\
\left({ }^{\circ} \mathrm{C}\right)\end{array}$ & $\begin{array}{c}\mathrm{PD} \\
(\mathrm{mmWG})\end{array}$ & $\begin{array}{c}P_{\mathrm{s}, 17.5} \\
\text { (mmWG) }\end{array}$ & $\begin{array}{c}\mathrm{T} \\
\left({ }^{\circ} \mathrm{C}\right)\end{array}$ & $\begin{array}{c}\text { PD } \\
(\mathrm{mmWG})\end{array}$ & $\begin{array}{l}\mathrm{PD}_{\mathrm{s}, 17.5} \\
\text { (mmWG) }\end{array}$ \\
\hline 18.2 & 194.1 & 195.8 & 18.4 & 401.1 & 404.5 & 18.4 & 587.9 & 592.8 & 18.4 & 783.4 & 789.8 \\
\hline 18.3 & 194.1 & 195.7 & 18.4 & 401.1 & 404.4 & 18.4 & 588.1 & 593.0 & 18.5 & 783.6 & 789.8 \\
\hline 20.2 & 195.0 & 195.8 & 20.2 & 402.9 & 404.6 & 20.0 & 590.8 & 593.6 & 19.8 & 786.5 & 790.7 \\
\hline 20.3 & 195.0 & 195.8 & 20.2 & 402.9 & 404.6 & 20.0 & 590.8 & 593.6 & 19.8 & 786.5 & 790.7 \\
\hline 21.5 & 195.6 & 195.8 & 21.4 & 403.4 & 404.0 & 21.3 & 591.5 & 592.5 & 21.0 & 786.9 & 788.8 \\
\hline 21.6 & 195.5 & 195.7 & 21.4 & 403.3 & 403.9 & 21.3 & 591.6 & 592.6 & 21.0 & 786.7 & 788.7 \\
\hline 22.0 & 195.6 & 195.7 & 22.1 & 403.7 & 403.9 & 22.2 & 592.6 & 592.9 & 22.2 & 788.9 & 789.5 \\
\hline 22.0 & 195.6 & 195.7 & 22.1 & 403.9 & 404.1 & 22.2 & 592.8 & 593.2 & 22.2 & 788.9 & 789.5 \\
\hline 22.8 & 196.2 & 195.9 & 22.9 & 404.7 & 404.0 & 23.1 & 592.9 & 591.7 & 23.1 & 789.8 & 788.2 \\
\hline 22.8 & 196.2 & 195.9 & 22.9 & 404.6 & 403.8 & 23.1 & 592.9 & 591.7 & 23.1 & 789.8 & 788.2 \\
\hline 23.9 & 196.4 & 195.6 & 24.2 & 406.4 & 404.6 & 24.2 & 595.4 & 592.9 & 24.2 & 792.0 & 788.8 \\
\hline 23.9 & 196.4 & 195.6 & 24.2 & 406.3 & 404.5 & 24.3 & 595.5 & 593.0 & 24.3 & 792.4 & 789.2 \\
\hline 26.4 & 197.5 & 195.6 & 26.5 & 407.4 & 403.6 & 26.3 & 597.7 & 592.5 & 26.0 & 795.0 & 789.0 \\
\hline 26.5 & 197.4 & 195.5 & 26.5 & 407.4 & 403.6 & 26.3 & 597.7 & 592.5 & 26.0 & 795.0 & 789.0 \\
\hline 27.8 & 198.4 & 195.9 & 28.0 & 409.3 & 404.3 & 28.2 & 600.1 & 592.6 & 28.3 & 797.2 & 787.6 \\
\hline 27.9 & 198.3 & 195.8 & 28.0 & 409.4 & 404.4 & 28.2 & 600.4 & 592.9 & 28.3 & 797.2 & 787.6 \\
\hline$s$ & 1.31 & 0.11 & $s$ & 2.61 & 0.36 & $s$ & 3.81 & 0.54 & $s$ & 4.43 & 0.91 \\
\hline
\end{tabular}




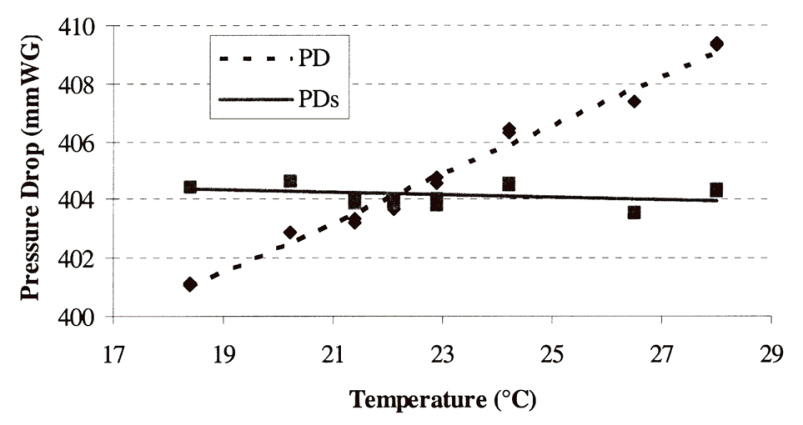

Figure 10. Compensation for ambient temperature effects (with $\mathrm{RH}=59 \%, P_{\text {atm }}=1005 \mathrm{hPa}$ )

sensitivity of PD to the RH $\left(S_{\%-T h}\right)$, deduced from the model developed above, has been compared with the value deduced from the measurements $\left(S_{\% \text {-Exp }}\right)$. Both sensitivity assessments are very similar and show that the PD decreases slightly when the RH increases.

For each measurement, the degree of non-linearity was estimated from the observed PD-value using the linear relationship drawn in Figure 8. The compensation formula was then applied using the estimated degree of non-linearity and the Eqns. [5] to [8]. Compensation produced the results given in Table 4.

Table 4 only shows a decrease in the standard deviation for the highest PD level. The measured variation of the PD vs. $\mathrm{RH}$ seems to be so slight, that the compensation has no significant effect on the standard deviation. The poor efficiency of the compensation may be explained by the low sensitivity of PD values to RH when combined with the natural variation of the measurements.

\section{Application to a long-term calibration}

To complete the experiments, the compensation formula was applied to 29 calibration results measured in the same laboratory with two standards (400 and $800 \mathrm{mmWG} \mathrm{PD}$ level) over a period of two months. During this period, the temperature varied from $20.1{ }^{\circ} \mathrm{C}$ to $23.9{ }^{\circ} \mathrm{C}$, the atmospheric pressure from $1000 \mathrm{hPa}$ to $1025 \mathrm{hPa}$ and the $\mathrm{RH}$ from $58 \%$ to $64 \%$. The results of the compensation are given in the Table 5 .
Table 5. Compensation results with standards calibrated over a period of time. Standard deviation before $\left(s_{\mathrm{PD}}\right)$ and following compensation ( $\left.s_{\mathrm{PDs}}\right)$

\begin{tabular}{c|c|c|c}
\hline \multicolumn{2}{c|}{$400 \mathrm{mmWG}$} & \multicolumn{2}{c}{$800 \mathrm{mmWG}$} \\
\hline $\begin{array}{c}s_{\mathrm{PD}} \\
(\mathrm{mmWG})\end{array}$ & $\begin{array}{c}s_{\mathrm{PDs}} \\
(\mathrm{mmWG})\end{array}$ & $\begin{array}{c}s_{\mathrm{PD}} \\
(\mathrm{mmWG})\end{array}$ & $\begin{array}{c}s_{\mathrm{PDs}} \\
(\mathrm{mmWG})\end{array}$ \\
\hline 1.26 & 0.66 & 2.42 & 1.29 \\
\hline
\end{tabular}

By using the compensation formula, the standard deviation is approximately halved. The benefit of the compensation and the efficiency of the developed simplified model are then clearly demonstrated, and validate the assumptions.

\section{A SIMPLIFIED MATHEMATICAL FORMULA}

At the request of users, an equivalent mathematical formula was developed, avoiding an iterative solution of the physical equations and allowing, easier application of the compensation. The relative variation of the PD value $(\alpha)$ was modelled by considering the effects of a variety of external influences. By eliminating all statistically insignificant terms, the following relation has been obtained:

$$
\begin{aligned}
\alpha= & \frac{\Delta \mathrm{PD}}{\mathrm{PD}_{\text {Meas }}}(\%)=\Delta T \times\left(a_{1}+a_{2} \times \mathrm{PD}_{\text {Meas }}\right) \\
& +\Delta P_{\mathrm{atm}} \times\left(a_{3}+a_{4} \times \mathrm{PD}_{\text {Meas }}\right)+a_{5} \times \Delta \mathrm{RH}+a_{6} \times\left(\Delta P_{\mathrm{atm}}\right)^{2}
\end{aligned}
$$

with difference $\Delta T$ between the ambient temperature and $22{ }^{\circ} \mathrm{C}$; difference $\Delta P_{\text {atm }}$ between the atmospheric pressure and $1013 \mathrm{hPa}$ (expressed in mmWG); difference $\Delta \mathrm{RH}$ between the $\mathrm{RH}$ and $60 \%$; $\mathrm{PD}_{\text {Meas }}$, the pressure measured in mmWG; $R^{2}=99.94 \% ; a_{1}=-2.404 \times 10^{-1} ; a_{2}=2.240 \times$ $10^{-5} ; a_{3}=-2.891 \times 10^{-3} ; a_{4}=-6.678 \times 10^{-6} ; a_{5}=2.707 \times$ $10^{-3} ; a_{6}=7.386 \times 10^{-6}$.

The compensated PD value is calculated using the following formula:

\begin{tabular}{|c|c|c|c|c|c|c|c|}
\hline \multicolumn{2}{|c|}{$200 \mathrm{mmWG}$} & \multicolumn{2}{|c|}{$400 \mathrm{mmWG}$} & \multicolumn{2}{|c|}{$600 \mathrm{mmWG}$} & \multicolumn{2}{|c|}{$800 \mathrm{mmWG}$} \\
\hline $\begin{array}{c}S_{\%-T h} \\
\text { (\%PD/\%RH) }\end{array}$ & $\begin{array}{c}S_{\% \text {-Exp }} \\
(\% \mathrm{PD} / \% \mathrm{RH}) \\
\end{array}$ & $\begin{array}{c}S_{\%-\mathrm{Th}} \\
(\% \mathrm{PD} / \% \mathrm{RH})\end{array}$ & $\begin{array}{c}S_{\%-E x p} \\
(\% \mathrm{PD} / \% \mathrm{RH}) \\
\end{array}$ & $\begin{array}{c}S_{\%-\text { Th }} \\
(\% \mathrm{PD} / \% \mathrm{RH}) \\
\end{array}$ & $\begin{array}{c}S_{\%-\text { Exp }} \\
(\% \mathrm{PD} / \% \mathrm{RH}) \\
\end{array}$ & $\begin{array}{c}S_{\% / \text { Th }} \\
(\% \mathrm{PD} / \% \mathrm{RH})\end{array}$ & $\begin{array}{c}S_{\%-E x p} \\
(\% P D / \% R H) \\
\end{array}$ \\
\hline-0.003 & $-0.003 \pm 0.003$ & -0.003 & $-0.007 \pm 0.004$ & -0.003 & $-0.003 \pm 0.003$ & -0.003 & $-0.002 \pm 0.001$ \\
\hline
\end{tabular}

Table 3. Relative sensitivity $S_{\%}$, of PD to the relative humidity; theoretical $\left(S_{\% \text {-Th }}\right)$ and experimental $\left(S_{\% \text { Exp }}\right)$ assessment

Table 4. Standard deviation before $\left(s_{\mathrm{PD}}\right)$ and following compensation $\left(s_{\mathrm{PDs}}\right)$

\begin{tabular}{c|c|c|c|c|c|c|c}
\hline \multicolumn{2}{c|}{$200 \mathrm{mmWG}$} & \multicolumn{2}{c|}{$400 \mathrm{mmWG}$} & \multicolumn{2}{c|}{$600 \mathrm{mmWG}$} & \multicolumn{2}{c}{$800 \mathrm{mmWG}$} \\
\hline $\begin{array}{c}s_{\mathrm{PD}} \\
(\mathrm{mmWG})\end{array}$ & $\begin{array}{c}s_{\mathrm{PDs}} \\
(\mathrm{mmWG})\end{array}$ & $\begin{array}{c}s_{\mathrm{PD}} \\
(\mathrm{mmWG})\end{array}$ & $\begin{array}{c}s_{\mathrm{PDs}} \\
(\mathrm{mmWG})\end{array}$ & $\begin{array}{c}s_{\mathrm{PD}} \\
(\mathrm{mmWG})\end{array}$ & $\begin{array}{c}s_{\mathrm{PDs}} \\
(\mathrm{mmWG})\end{array}$ & $\begin{array}{c}s_{\mathrm{PD}} \\
(\mathrm{mmWG})\end{array}$ & $\begin{array}{c}s_{\mathrm{PDs}} \\
(\mathrm{mmW})\end{array}$ \\
\hline 0.12 & 0.18 & 0.53 & 0.53 & 0.42 & 0.48 & 0.72 & 0.33 \\
\hline
\end{tabular}




$$
\begin{gathered}
\mathrm{PD}_{\mathrm{S}, 17.5 \mathrm{~mL} / \mathrm{s}} \cong\left[\mathrm{PD}_{1} \times\left(\frac{17.5}{Q}\right)^{2}+\mathrm{PD}_{2} \times\left(\frac{17.5}{Q}\right)\right] \times\left(1+\frac{\alpha}{100}\right) \\
\mathrm{PD}_{1}=x \times \mathrm{PD}_{\text {Meas }} \text { and } \mathrm{PD}_{2}=(1-x) \times \mathrm{PD}_{\text {Meas }} \\
x=3.41 \times 10^{-5} \times \mathrm{PD}+3.38 \times 10^{-2}
\end{gathered}
$$

\section{CONCLUSION}

Experiments clearly show that the airflow through a multicapillary standard is partly non-linear. A simplified model was developed, that includes a parameter related to the degree of non-linearity varying from 3.9 to $6 \%$. The use of this model allows successful compensation for the effects of atmospheric pressure and ambient temperature. The sensitivity of the PD to the RH is so low that compensation seems unnecessary for this parameter but is retained in the formula. Finally, in order to facilitate the compensation process, a mathematical formula is proposed.

\section{REFERENCES}

1. VDI-Waermeatlas: Druckverlust bei der Strömung durch Leitungen bei Querschnittsänderungen; 8th Ed., VDI, 1997, Lc1.

2. Rasmussen, K.: Calculation methods for the physical properties of air used in the calibration of microphones; Technical University of Denmark; Report PL-11b, 1997, http//www.dat.dtu.dk/docs/PL11b-RAP.PDF.

3. Formulaire Technique, Giek, 10ème édition française, 1997.

4. Keith, C.H. and J.A. Corbin: Multiple capillary pressure drop standards; Beitr. Tabakforsch. 8 (1975) 60-64.

\section{Address for correspondence}

Stéphane Colard

ALTADIS Research Centre

4 rue André Dessaux

45404 Fleury-Les-Aubrais, France 